\title{
A német LK II és a svéd Strv m/21 típusú harckocsik, valamint magyar vonatkozásaik tr.resz
}

A két világháború között - politikai és gazdasági okok miatt - több ponton is kapcsolatot fedezhetünk fel a Magyar Királyság és az attól földrajzilag meglehetősen távol eső Svédország harckocsijainak történetében. Pár évvel a harckocsit, mint harceszközt „életre hívó" első világháború után mindkét ország - még ha más-más körülmények között is - gyakorlatilag ugyanazt a típust, a német Leichter Kapfwagen II, röviden LK II típusú könnyű harckocsit rendszeresítette először hadseregében. Magyarország 1920 tavaszán a nemzetközi ellenőrzést kijátszva összesen 14 darab ilyen harckocsihoz jutott hozzá egyelöre nem teljesen tisztázott körülmények között. A svédek pedig, miután kudarcba fulladt a világháborút követő próbálkozásuk, hogy brit harckocsikat vásároljanak maguknak, 1921ben - szintén nemzetközi megállapodásokat sértve - a legnagyobb titoktartás mellett 10 darab, a németek által a háború befejezése miatt össze nem szerelt LK II-es harckocsit vásároltak ${ }^{1}$ a versailles-i békeszerződés értelmében lefegyverzett német hadsereg készleteiből.

Ezt követően a két ország páncélosainak története az 1930-as évek végén újból összetalálkozott, amikor az ekkorra már önálló harcjármű fejlesztő és -gyártó hatalommá fejlődött svéd hadiipar szolgáltatta az első hadrendbe állított magyar gyártmányú páncélos, a 38M Toldi I könnyű harckocsi előfutárának, a Landsverk L-60-nak a terveit. Ugyanekkor szerezte be a Magyar Királyi Honvédség a szintén Svédországban kifejlesztett Landsverk L-62 licencét is, ami pedig így a magyar 36/40M Nimród önjáró páncélvadász és légvédelmi gépágyú elődje lett. Nem sokkal ezután pedig csak az elhúzódó fejlesztés és a politikai helyzet változása akadályozta meg, hogy az első magyar közepes harckocsi - amely végül a csehszlovák Škoda

ÖSSZEFOGLALÁS: Az első világháború legvégén a Német Császárság kísérletet tett egy saját könnyü harckocsi kifejlesztésére, amelynek egyik eredménye a Leichter Kampfwagen II, röviden LK II-es lett. Ez azonban túl későn készült el ahhoz, hogy a harcokban bevethető legyen. A háborút követően nem teljesen tisztázott körülmények között - több példány is először a Magyar Királyságban, majd Svédországban bukkant fel. A magyaroknak a típust 1920-tól 1927-ig rejteniük kellett az antant ellenőrzés elől, majd azt követően 1933-ig kiképzési célokra használták a harckocsikat. Mindeközben a svédek, egy német cég közvetítésével még 1921-ben 10 darab, össze nem szerelt LK II-est vásároltak a leszerelt német hadsereg hadianyag-készleteiből, amelyek svédországi összeszerelésüket követően a svéd hadseregben a Stridsvagn m/21, röviden Strv m/21-es nevet kapták. A típust 1928-ra elavultnak minősítették, de leváltására más külföldi páncélos típust nem találván, a megmaradt példányok felújitása és további használata mellett döntöttek. A modernizált változat az Strv m/21-29-es nevet kapta, és egészen 1938-ig állt szolgálatban a svéd haderőben.

KULCSSZAVAK: két háború közötti időszak, Leichter Kampfwagen II, Stridsvagn $\mathrm{m} / 21$, svéd harckocsi, magyar páncélos
T-21 módosított változata lett 40M Turán I néven - is a Toldival sok közös jeggyel rendelkező svéd Landsverk Lago közepes harckocsi legyen. Mindezek ellenére magyarul eddig igen keveset lehetett olvasni a néha magyar vonatkozásokkal is rendelkező svéd harckocsikról.

Ebben a cikkben az LK II-es harckocsi német, magyar és svéd alkalmazásának történetét, vélt és valós kapcsolataikat, illetve a svéd páncélos fegyvernem létrejöttében játszott szerepét szeretném bemutatni a legfrissebb nemzetközi kutatási eredményeket is felhasználva.

\section{EGY MEGKÉSETT ELSŐ VILÁGHÁBORÚS PÁNCÉLOS - A NÉMET LK II KÖNNYŰ HARCKOCSI}

A Leichter Kampfwagen - magyarul szó szerint „könnyü harckocsi” - elnevezésű páncélosok fejlesztése az első világháború alatt, 1917 szeptemberében kezdődött a Német Császárságban Joseph Vollmer ${ }^{2}$ vezetésével. Vollmer ekkor, az általa tervezett 30 tonnás, 18-23 fő által üzemeltetett német „mozgó erőd”, a Sturmpanzerwagen A7V harckocsi első próbadarabjainak bemutatását követően vetette fel, hogy szükség lenne egy ennél a típusnál jobb mozgékonysággal bíró páncélosra is. Elképzelését ugyanaz motiválta, mint az időben vele nagyjából párhuzamosan zajló antant könnyűharckocsik-fejlesztését. A gyakorlat bebizonyította ugyanis, hogy az 1916 szeptemberétől bevetett első harckocsik, mint amilyenek a brit romboid alakú tankok, majd nem sokkal később az első francia páncélosok, vagy az 1917 végétől kis számban hadrendbe álló A7V-k is voltak, nem alkalmasak az ellenség vonalán történő áttörés sikerének kiaknázására, elsősorban a terepen

ABSTRACT: Right at the end of the First World War, the German Empire tried to create a domestic light tank design. This resulted in the Leichter Kampfwagen II light tank (LK II in short), which however came too late to be used during the conflict. Shortly after the war - between unclear circumstances - several units of this type of armored vehicle appeared firstly in the Kingdom of Hungary then in Sweden. The Hungarians had to conceal these tanks from Entente supervision until 1927. After that they were used as training vehicles until 1933. Meanwhile in 1921 the Swedes bought 10 unassembled LK II parts kits from the stocks of the disarming German Army, with the mediation of a private company. After their assembly in Sweden they recieved the designaton of Stridsvagn $m / 21$, or shortly Strv $m / 21$. The type was declared obsolete by 1928 , but since the Swedes did not find a decent replacement for this vehicle, it was decided that the remaining Strv $\mathrm{m} / 21 \mathrm{~s}$ shall be upgraded and further used. The modernized variant became the Strv m/21-29 which continued to be in service of the Swedish Army until 1938

KEY WORDS: interwar period, Leichter Kampfwagen II, Stridsvagn m/21, Swedish tank, Hungarian armoured vehicle 
1. ábra. Joseph Vollmer, az első világháborús német harckocsik „atyja” és az általa is tervezett A7V, a Német Császárság egyetlen saját gyártású harckocsija, amelyet a fronton is bevetettek
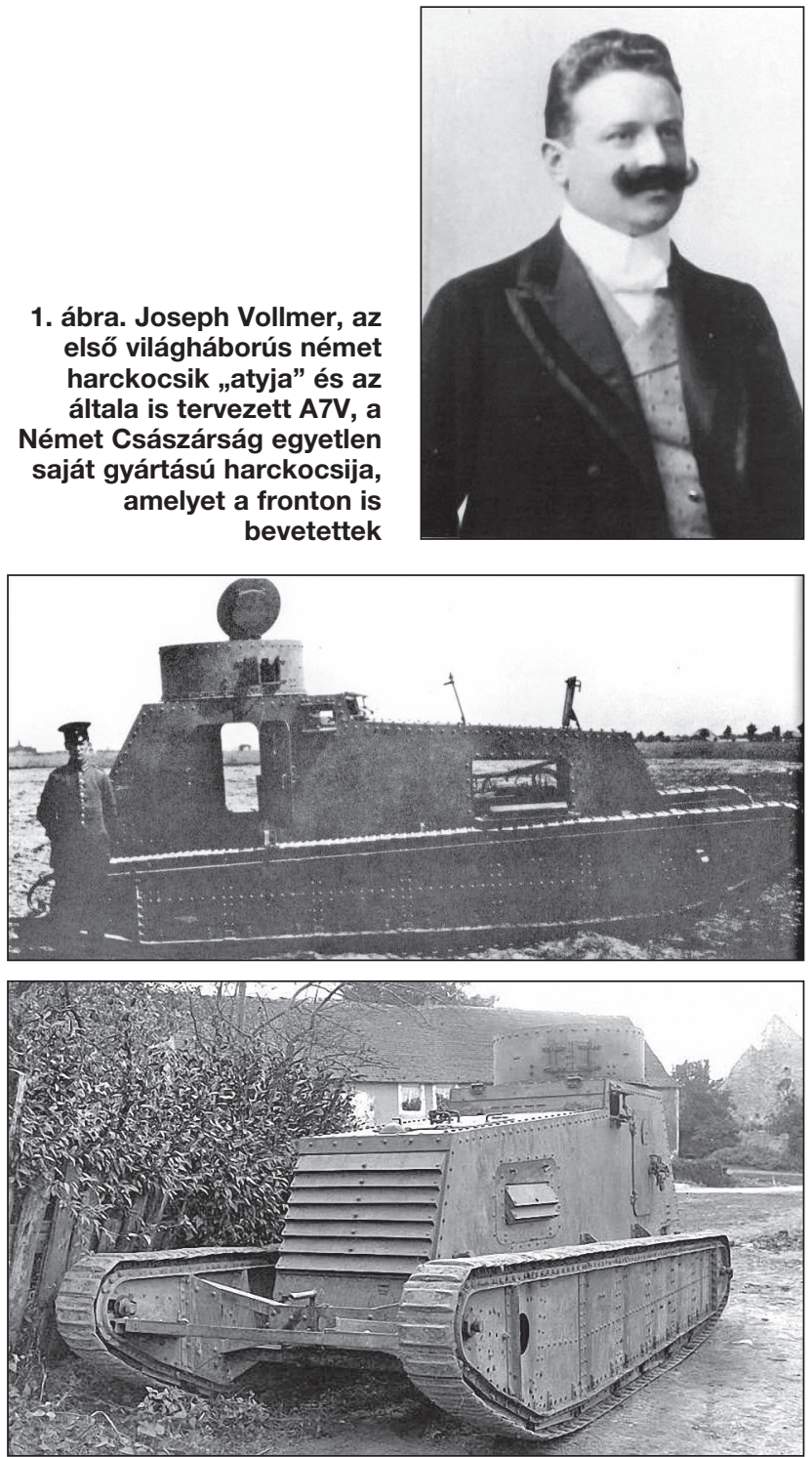

2. ábra. Az LK I-es oldal- és elülső nézete

történő nehézkes mozgásuk, lomhaságuk miatt. Szükség lett volna egy mozgékonyabb páncélos típusra is, ami nagyobb mozgékonyságát és sebességét kihasználva manőverező hadmozdulatokra, a nehezebb harckocsik által az arcvonalon ütött réseken keresztül gyors elöretörésre, az ellenség átkarolására, bekerítésére lehetett volna használni. A könnyű harckocsik szerepét ahhoz a taktikához hasonlították, ahogy a lovasságot alkalmazták a világháborús frontok megmerevedése és a géppuskák és tüzérség által uralt lövészárokharc kialakulása előtti hadszíntereken.

Az ilyen elveken alapuló antant könnyűpáncélosok fejlesztésével ellentétben a Vollmer által szorgalmazott német harckocsi létrehozása lassan haladt, ugyanis az eleve is kis prioritást élvező német harckocsi-fejlesztési programon belül a német császári hadvezetés inkább a szárazföldi csatahajókra emlékeztető, gigantikus, 100 tonnánál is nehezebb, áttörő szupernehéz páncélosok fejlesztését erőltette, mint amilyen a Großkampfwagen, más néven $\mathrm{K}$-Wagen lett volna. Így a Vollmer által vezetett tervezőrészleg idejét és energiáját túlnyomó többségben ennek létrehozása kötötte le, és csak részben foglalkozhattak a könnyű páncélos típus megtervezésével.
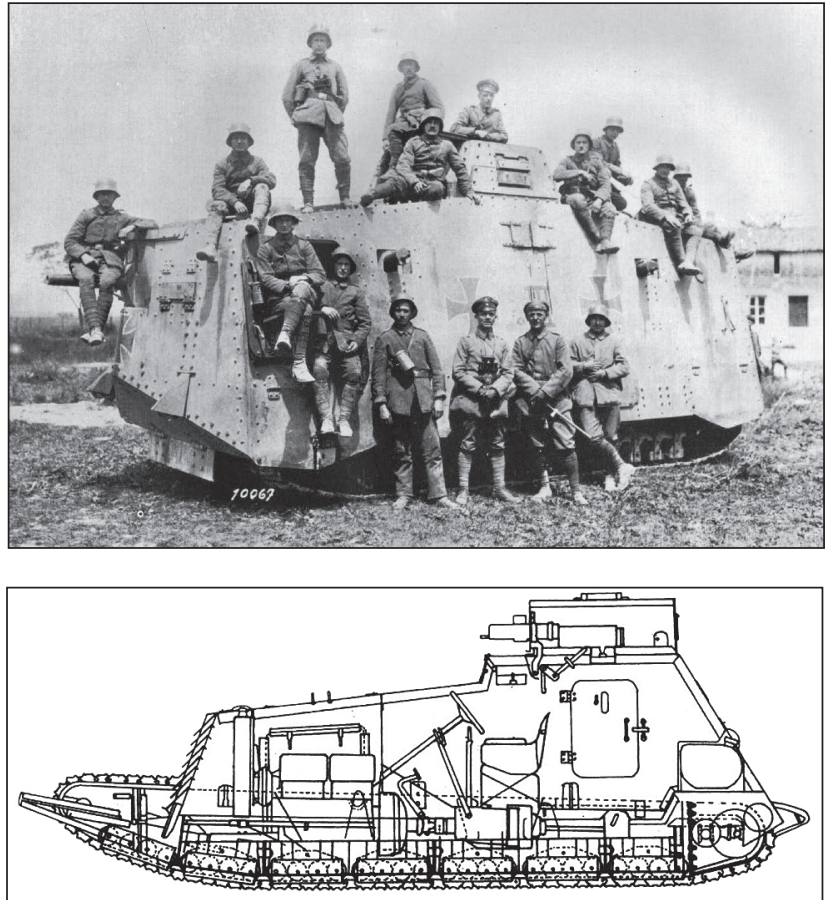

3. ábra. Az LK I keresztmetszete. Jól látszik, hogy mai szemmel nézve milyen kezdetleges és viszonylag egyszerú hadigép is volt ekkoriban egy harckocsi

1918 márciusáig - amikorra az antant már elkezdte bevetni a hasonló elképzelést tükröző francia Renault FT, illetve a brit Medium Mark A Whippet könnyű, gyalogságtámogató harckocsikat - mindössze egy mintapéldány készült el a Vollmer által megálmodott német könnyű páncélosból. Ez a kezdetleges, egy Mercedes személyautó alváznak, alkatrészeinek és motorjának felhasználásával épült német kísérleti harckocsi a Leichter Kampfwagen Modell I, röviden LK I nevet kapta.

$A z$ addig bevetett legtöbb harckocsihoz képest az LK I-es kevesebb, mint 7 tonnájával „,pehelysúlyúnak” számított és végsebessége meghaladta az addigi, csak gyalogtempóra képes, nehézkes behemótokét. A típus megtartotta az alapjául szolgáló gépkocsi eredeti kialakítását, így a motortér a harckocsi orr-részében kapott helyet, és a meghajtott kerék (ez esetben lánckerék) is a hátsó maradt. A felfüggesztés a korai lánctalpas mezőgazdasági vontatóktól eredeteztethető, és a hátsó, meghajtott lánckerékből, az elől lévő láncfeszítő kerékből, a négyesével összekapcsolt, rugózott, kis-

4. ábra. A brit Medium Mark A Whippet harckocsi. Megjelenése a nyugati front csataterein szemmel láthatóan hatást gyakorolt a német Leichter Kampfwagen továbbfejlesztésére is

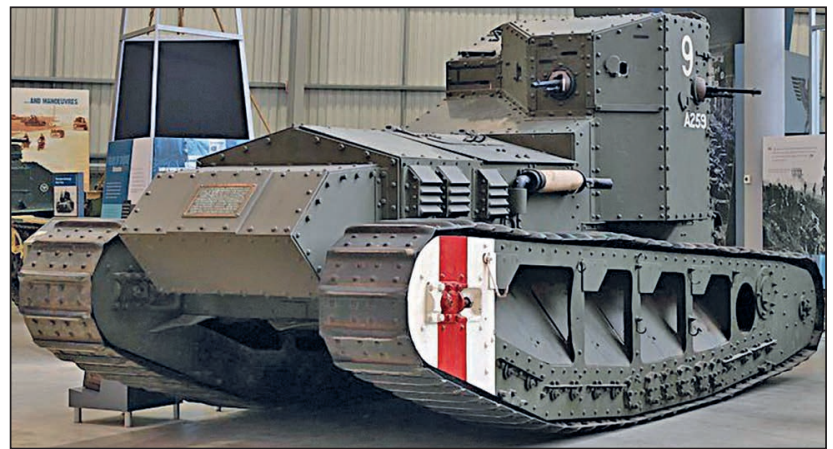



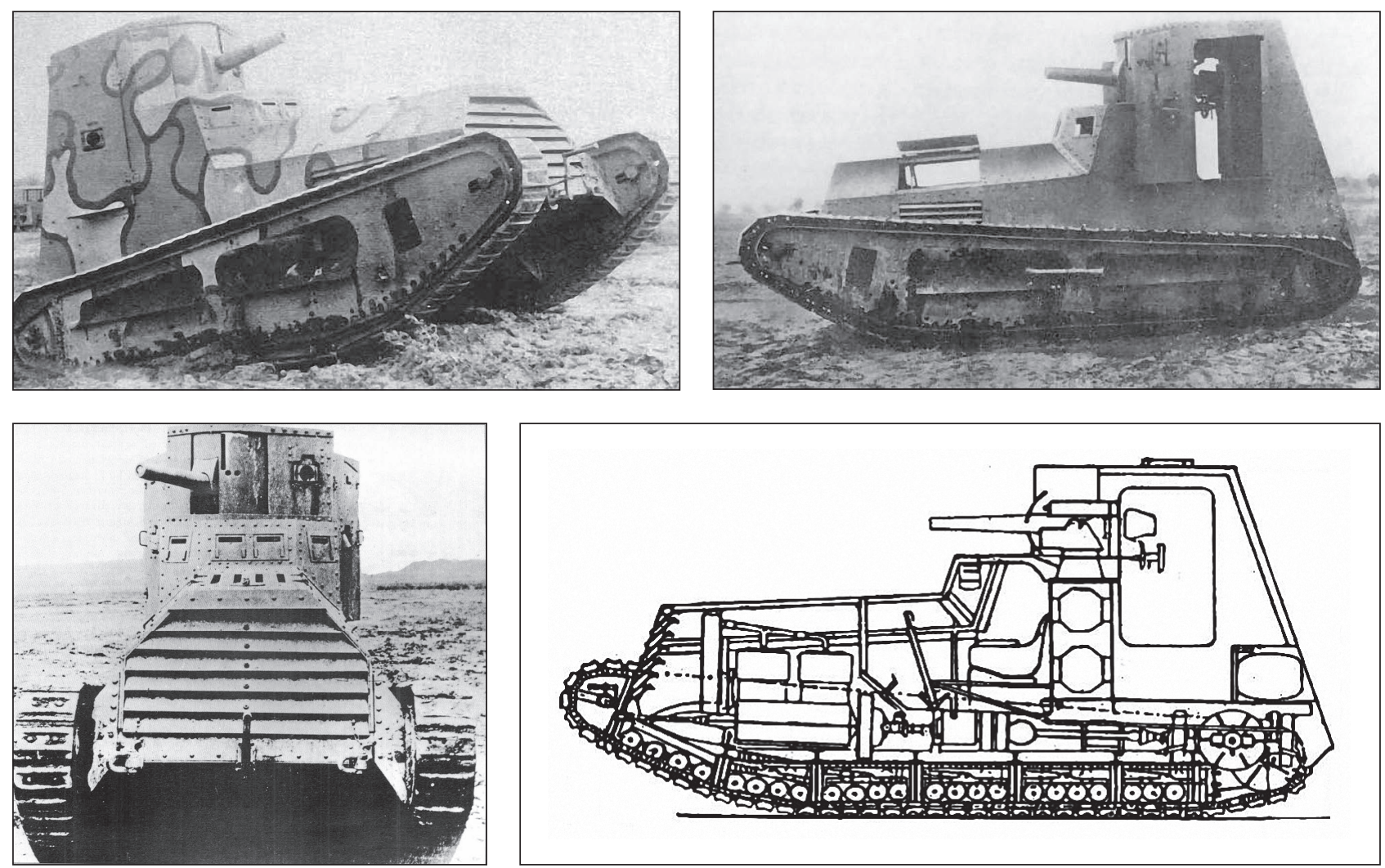

5. ábra. Az LK II-es forgótorony nélküli, 57 mm-es ágyúval szerelt változata. Jól látszik az LK I-estől örökölt hátrafelé dőlő orr-rész, amelyen még nyitható-zárható páncélzsaluzaton keresztül áramolhatott a motor hütését biztosító levegő a motortérbe

méretű futógörgőkből, valamint egyszerü láncból állt. A kétvagy háromfős küzdőteret a harcjármű hátuljában alakították ki, amelynek tetején a körbe forgatható toronyba szerelt fő fegyverzet, egy vízhútéses, 7,92 mm-es MG 08 géppuska kapott helyet. Az LK I-es páncélzatának vastagsága nem haladta meg a $8 \mathrm{~mm}$-t, ami így az ellenséges kézifegyverek, géppuskák közvetlen közelről leadott tüzének sem tudott teljes mértékben ellenállni. A próbadarabbal végzett kísérletek alapján azonban a császári haderő - akkorra már - ígéretesnek találta az elképzelést, és szorgalmazta egy javított változat megépítését.
Egy további prototípus épült 1918 nyarán, a továbbfejlesztett, vastagabb, ellenséges kézifegyverek tüzének ellenállni képes páncélzattal, rövidebb, javított futóműrendszerrel $^{3}$ és erősebb motorral szerelt változatból, a Leichter Kampfwagen Modell II-esből, LK II-esből. Ezt az akkori elképzelések szerint kétféle változatban gyártották volna. Az egyik változatot az LK I-esen már kipróbált, forgótoronyba szerelt géppuskával látták volna el, míg a másik változatot forgótorony nélküli, a harckocsi hátulján kialakított páncélozott felépítményben elhelyezett ágyúval fegyverezték volna fel. Az LK II-es prototípusa ilyen ágyús kivitelben

\section{6. ábra. Az LK II-es felfüggesztésének egy eredeti tervrajza}

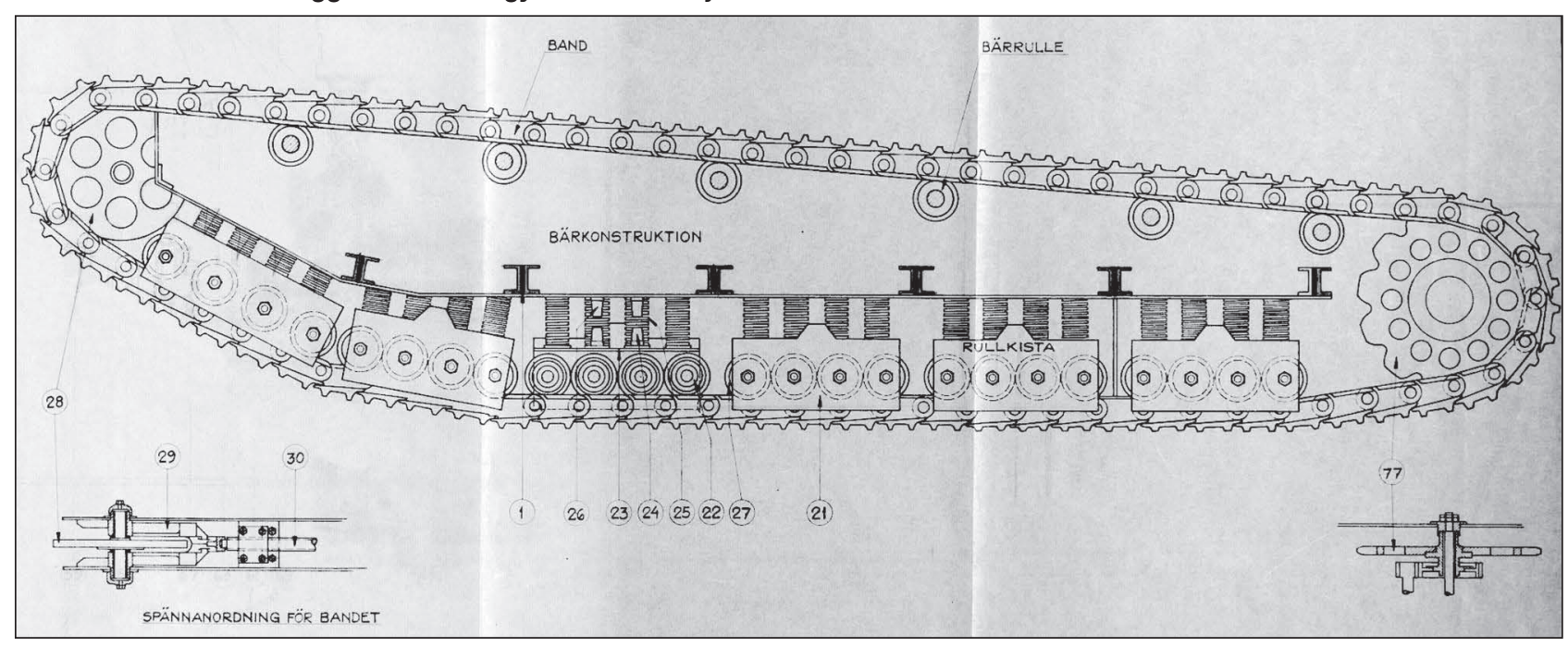



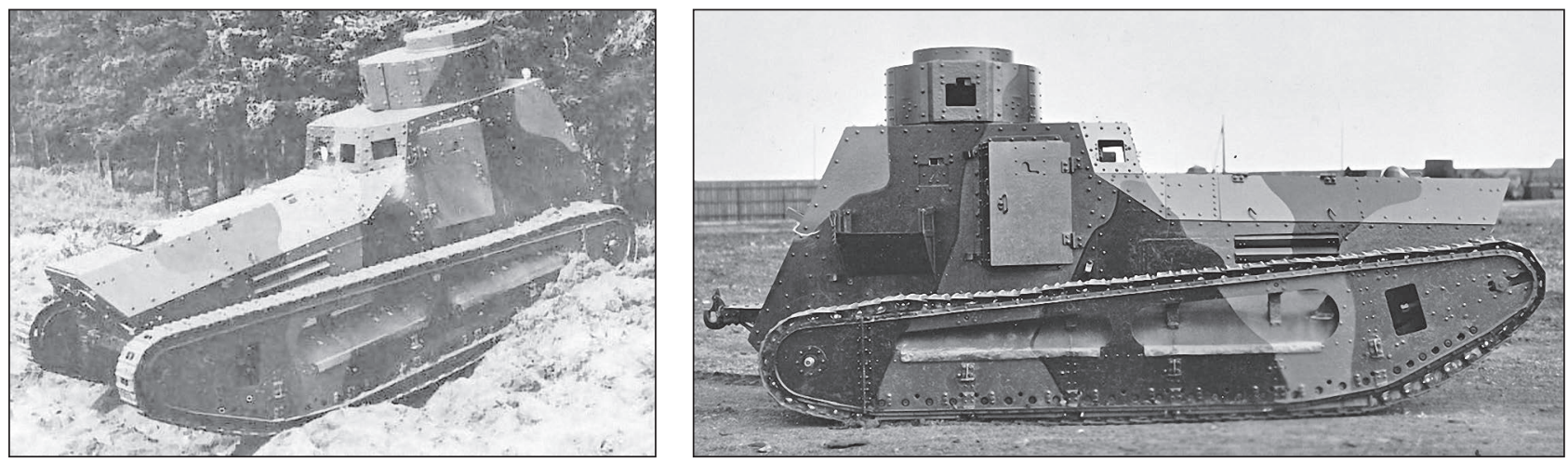

7. ábra. A svéd Stridsvagn $\mathrm{m} / 21$-es. Így nézett volna ki a német LK II-es sorozatgyártott, forgótoronyba szerelt géppuskás változata is, ha a háború nem ért volna véget a tömeggyártás beindulása előtt

épült meg. Ebbe a változatba az első kísérletek során, 1918 augusztusában egy - az A7V harckocsin is alkalmazott - 57 mm kaliberű Maxim-Nordenfelt löveget szereltek, ami azonban méretben túl nagynak bizonyult, és a löveg visszarúgása túlságosan is megterhelte a harckocsi felépítményét. Így ezt később egy kisebb, 37 mm-es lövegre cserélték volna le.

A mintadarabbal végzett gyakorlati próbák eredményeit összegezve, 1918 őszén az ágyús prototípushoz képest átalakították az LK II-es harckocsi testének elejét, orr-részét. Ennek során a korábbi hátrafelé dőlő orr kialakítást, és a nyitható-zárható páncélzsalukkal védett levegőnyílást előrefelé dőlő, zárt orrpáncélra és az orr-rész tetején kialakított lég-beömlőkre cserélték le, mivel a korábbi zsaluzat a próbák alapján nem biztosított kellő védelmet az ellenséges tűzzel szemben. Ezt követően nyerte el a sorozatgyártásra előkészített LK II-es a végsőnek szánt formáját. ${ }^{4}$ A háború vége előtt nem sokkal a német hadsereg 580 darabot rendelt ebből a véglegesített LK II-esből, amelyek kétharmada forgótorony nélküli ágyús-, míg egyharmada forgótoronyba szerelt géppuskás változatban épült volna meg, és az új harckocsikat először a tervezett 1919 tavaszi offenzívában vetették volna be. Erre azonban már nem került sor. A német haderő ellenállása 1918. szeptember végére összeomlott, és a novemberi, compiègne-i fegyverszünetig a prototípusokon kívül egy további „sorozatgyártott” LK II-est sem fejeztek be, bár több, géppuskával szerelt példány összeállításához elegendő alkatrész elkészült már.

A háború befejezése előtt nem sokkal Joseph Vollmer elkészítette az LK II-est későbbiekben leváltani hivatott LK III-as tervét is, amelyen a motor és a sebességváltó a szemből várható ellenséges tűztől jobban védve, a harckocsi hátuljában kapott volna helyet, és a harckocsi tornya a járműtest közepén helyezkedett volna el. Ennek a változatnak a tervrajzát azonban a háború vége miatt nem véglegesítették, és prototípus sem épült belőle.

A fegyverszünet megkötését követően tervben volt egy ideig, hogy a weimari köztársaság 100 darab harckocsit köztük javarészt LK Il-eseket - fog hadrendben tartani, azonban az 1919. június 28-án aláirt versailles-i békeszerződés értelmében annak életbelépésétől, 1920. január 10től kezdve, Németország a szigorú fegyverzeti korlátozások miatt nem rendelkezhetett egy darab harckocsival sem. Így az összeszerelésre váró - vagy feltételezhetően akár össze is szerelt - harckocsik sorsa elméletben alkatrészeik megsemmisítése, beolvasztása lett volna. A gyakorlatban mindazonáltal - a legnagyobb titoktartás mellett - jó pár ilyen fegyverzet nélküli LK II-es összeszereléséhez elegendő alkatrész talált ekkoriban új gazdára - jó pénzért, illegálisan - többek között a Magyar Királyságban, illetve

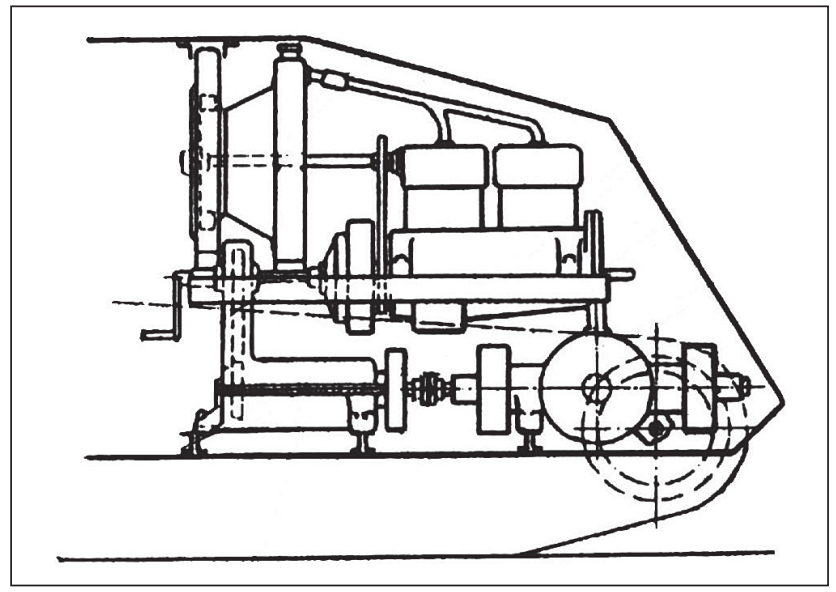

8. ábra. Az LK III-as hátul elhelyezett motorterét ábrázoló tervrajz. A prototípus a háború befejezése miatt már nem készült el

Svédországban, mint „lánctalpas mezőgazdasági vontató-”, vagy „traktor-alkatrész”.

\section{SvÉd köZvetítés? - az LK II MagyaroRSzÁGoN}

Érdekes párhuzam a svéd és a magyar harckocsik történetében, hogy 1920 tavaszán, még a trianoni béke megkötése előtt 2 próbadarabot, majd nem sokkal később további 12 darabot, tehát összesen 14 darab, össze nem szerelt, fegyverzet nélküli LK II-es harckocsit vásárolt titokban - a svédekhez hasonlóan - Magyarország is. Ennek a pontos körülményeit azonban egyelőre még nem sikerült tisztázni. Mindazonáltal a semleges svédekkel ellentétben, az első világháború vesztes oldalán álló magyaroknak az 1920. június 4-én megkötött trianoni békediktátum fegyverzeti korlátozásai miatt ${ }^{5}$ már tilos lett volna ilyen harceszközöket birtokolniuk. Emiatt a legnagyobb titokban, álítólag a Dunán uszályokban, gabona alá rejtve Magyarországra szállított LK II-eseket egészen 1927-ig szétszerelt állapotban rejteni kellett az ország különböző pontjain szétszórva, ${ }^{6}$ mivel az ellenséges államokkal körülzárt Magyar Királyság katonai és politikai vezetői nem kívántak megválni a nagy nehezen megszerzett páncélosoktól.

A békediktátumban előírt fegyverzeti korlátozások betartását ellenőrizni hivatott antant Szövetségközi Katonai Ellenőrzési Bizottság 1927. március végi megszűnését követően, a rossz tárolás következtében javarészt tönkrement, vagy a nagy titkolózásban elveszett alkatrészekből a ma- 


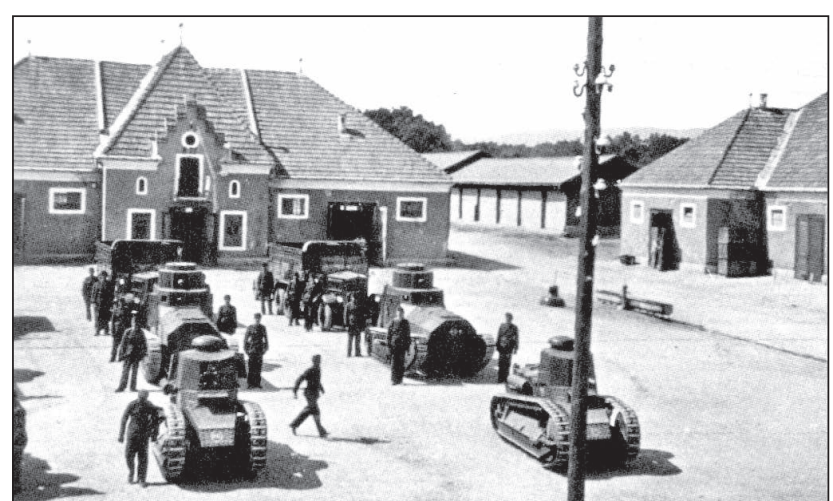

9. ábra. Német eredetű LK II-esek és Olaszországtól vásárolt FIAT 3000B típusú harckocsik magyar szolgálatban

gyarok 6 darab múködőképes LK II-est tudtak összeszerelni. Ezeket az elkövetkező pár évben, az 1930-as évek elejéig, eleinte a Belügyminisztérium alá tartozó „álcázott” katonai kiképzőközpont, a Rendőr Újonc Iskola (röviden RUISK), majd később a Magyar Királyi Honvédség használta kiképzési célokra. Használatba vételüket követően pár évvel - mivel ekkorra már rendelkezésre állt egy újabb, bár nem sokkal modernebb típus, az Olaszországtól vásárolt FIAT 3000-es a típust elavultnak minősítették és kiselejtezték. 1933-ra magyar LK II-esek kikerültek a szolgálati állományból és ócskavasként vagy lövészeti céltárgyként megsemmisültek.

Érdekesség, hogy a magyar LK II-esek egyik adminisztrációban elkallódott, elfeledett, békésen rozsdásodó utolsó példányára 1939-ben az örkénytábori laktanya egy elhagyatott, bedeszkázott fészerében találtak rá a frissen odavezényelt ceglédi II. lovasdandár könnyűharckocsiszázadának katonái. Miután századparancsnokuk utána érdeklődött a felsőbb vezetésnél, hogy mégis miért van az akkoriban már évek óta kivont harcjármű a megadott helyen és milyen sorsot szánnak neki, azt az - egyébként jellemző - választ kapta, hogy a típust a hadrendből már kivonták, példányait megsemmisítették, nem létezik. Így az alakulat katonái ennek megfelelően jártak el és a „nem létező” harckocsit „nem létező” alkatrészeire bontva, létező pénzért cserébe eladták. A befolyt összegből a körlet minden legénységi szobájába rádiót, valamint az alakulatnak két motorkerékpárt vásároltak, a maradék pedig a század rászorultjainak segélyezésére szánt bajtársi kasszába került. Tragikomikus hattyúdala volt ez az első magyarországi harckocsi történetének.

A korábban megjelent szakirodalom feltételez valamilyen svéd közvetítést is a Magyarország LK II-es vásárlásával kapcsolatban, erre azonban kézzel fogható bizonyíték vagy levéltári forrás eddig még nem került elő. Feltételezhetően az a közkeletű tévhit okozta a félreértést, amely szerint az LK II-es véglegesnek szánt, forgótoronyba szerelt géppuskával és előrefelé dőlő orr-résszel épített változatának kialakítása már Svédországban történt, így joggal lehetett volna feltételezni, hogy a Magyarországon megjelent, szintén forgótornyos és előrefelé dőlő orr-résszel rendelkező LK II-esek is onnan kell, hogy származzanak. Erre a legújabb kutatások eredményei már rácáfoltak, ugyanis német és svéd levéltári források alapján bizonyítható, hogy az LK II-esek - abban a formában, ahogy a svédek megvásárolták azokat -, már a háború utolsó hónapjaiban is léteztek - ha más nem, tervrajz és alkatrészek formájában -, s mind a svéd, mind a magyar LK II-esek már ennek a sorozatgyártásra szánt, német LK II-esnek az alakjában épültek meg. ${ }^{7}$

$A z$ a tény pedig kifejezetten valószínútlenné teszi ezt a svéd közbenjárást, hogy levéltári források alapján az első

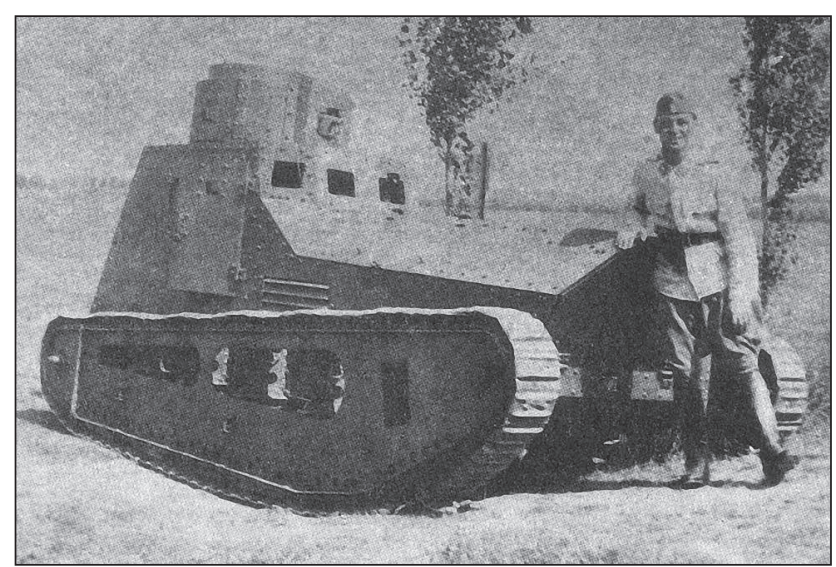

10. ábra. Egy magyar LK II-es Hajmáskéren, 1932-ben

LK II-esek Magyarországra 1920 tavaszán érkeztek, míg a svédek maguk bizonyíthatóan csak 1921 első hónapjaiban kezdtek hozzá a típus vásárlásával kapcsolatos németországi tárgyalásokhoz, illetve az első darabok alkatrészei is csak 1921 szeptemberétől érkeztek Stockholmba. Így sokkal valószínübbnek látszik, hogy a magyarok a legnagyobb titokban, vagy közvetlenül a háború után épp széthulló/újjászerveződő német államtól, vagy annak tudta nélkül német vállalatokon, magánszemélyeken keresztül vásárolták meg ezeket a harcjármúveket. A németeknek mindenesetre kapóra jött, hogy az amúgy is tiltólistára kerülő, megsemmisítésre váró harcjárműveket mihamarabb pénzzé tehették.

Összességében elmondható, hogy - nagyon is különböző sorsuk ellenére - mind Magyarország, mind Svédország első harckocsi típusa ugyanaz a háború legvégén kifejlesztett LK II-es volt, amely túl későn érkezett ahhoz, hogy Németország oldalán részt vehessen az első világháborús harcokban.

$$
\text { (Folytatjuk) }
$$

\section{FELHASZNÁLT IRODALOM}

- Baadstöe, Christer: How the Swedish Armoured Corps was born https://www.sphf.se/svenskt-pansar/historia/ how-the-swedish-armoured-corps-was-born/ (Utolsó megtekintés: 2018.10.11.);

- Blomster, Karl és Norlund, Viktor levéltári gyűjteményei;

- Bartholomew, E.: First World War Tanks. Shire Publications, Bucks (1986). 22-23. o.;

- Bíró Ádám - Éder Miklós - Sárhidai Gyula: A Magyar Királyi Honvédég külföldi gyártású páncélos harcjárművei 1920-1945. Petit Real, Budapest (2006). 9., 16. o.;

- Bíró Ádám - Sárhidai Gyula: A Magyar Királyi Honvédég hazai gyártású páncélos harcjármúvei 1914-1945. Petit Real, Budapest (2012). 40-45. o.;

- Bíró Ádám: A páncélos fegyvernem megteremtésének kezdetei a Magyar Királyi Honvédségben - az LK-II és a FIAT 3000 B. In.: Haditechnika, 1993/3. 61-65. o.;

- Bombay László - Gyarmati József - Turcsányi Károly: Harckocsik 1916-tól napjainkig. Zrínyi, Budapest (1999). 40-44., 51-52., 58., 60. o.;

- Bonhardt Attila - Pánczél Mátyás - Végh Ferenc - Szekeres József - Hattyár István - Sári Szabolcs: A magyar páncélosalakulatok története. Zrínyi, Budapest (2015). 42-54. o.;

- Bonhardt Attila - Sárhidai Gyula - Winkler László: A Magyar Királyi Honvédség fegyverzete. Zrínyi, Budapest (1995). 13-15., 48. o.; 
- Éder Miklós: Az LK-II. német könnyűharckocsi magyar szolgálatban. In: Militaria Modell 1992/2. 12-13. o.;

- Edwards, Robert J.: Panzers Forward - A Photo History of German Armor in World War II. Stackpole Books, Lanham MD (2018). 2. o.;

- Fleischer, Wolfgang: Military Vehicles of the Reichswehr. Schiffer Publishing, Atgen PA (1996). 3. o.;

- Haupt, Werner: A History of the Panzer Troops 1916-1945. Schiffer Publishing, Atgen PA (1990). 15. o.;

- Janson, O.: The Swedish machineguns before 1950. http://www.gotavapen.se/gota/artiklar/utv_ksp58/ ksp14/2_ksp14.htm (Utolsó megtekintés: 2018.09.01.);

- Jones, Ralph E. - Rarey, George H. - Icks, Robert J.: The Fighting Tanks since 1916. The National Service Publishing, Washington D.C. (1933). 139-140. o.;

- Lindström, Rickard O.: Strv m/21. http://www.ointres. se/strv_m_21.htm (Utolsó megtekintés: 2018.10.11.);

- Lindström, Rickard O.: Strv Renault FT17 \& NC27. http://www.ointres.se/strv_renault.htm (Utolsó megtekintés: 2018.10.11.);

- Moore, Craig: Tank Hunter - World War One. The History Press, Gloucestershire (2017). 65-68.;

- Mujzer Péter: A magyar páncélos fegyvernem kezdetei. I. rész. In: Haditechnika 2016/1. 3-4. o.;

- Пашолок, Юрий (Pasolok, Jurij): Первый танк шведской армии. https://warspot.ru/8156-pervyy-tankshvedskoy-armii (Utolsó megtekintés: 2018.10.11.);

- Пашолок, Юрий (Pasolok, Jurij): С прицелом на экспорт. https://warspot.ru/5917-s-pritselom-naeksport .Az eredetileg orosz nyelven megjelent cikk angol fordítása: http://tankarchives.blogspot. com/2017/05/renault-nc-destined-for-export.html. (Utolsó megtekintés: 2018.10.11.);

- Пашолок, Юрий (Pasolok, Jurij): Трудный выбор шведской армии. https://warspot.ru/8916-trudnyyvybor-shvedskoy-armii. Az eredetileg orosz nyelven megjelent cikk angol fordítása: http://tankarchives. blogspot.com/2017/11/the-swedish-armys-toughchoice.html. (Utolsó megtekintés: 2018.10.11.);

- Poór István (főszerk.): Harckocsi típuskönyv. Zrínyi, Budapest (1980). 202. o.;

- Schneider, Wolfgang - Strasheim, Rainer: German Tanks in World War I - The A7V and Early Tank Development. Schiffer Publishing, West Chester PA (1990). 42-46. o.;

- Varga A. József (szerk.): Magyar autógyárak katonai jármúvei. Maróti, Budapest (2008). 61-62., 203-205. o.;

- White, Brian Terence: German Tanks \& Armored Vehicles 1914-1945. Arco, New York (1968). 26-27.;

- White, Brian Terence: Tanks and Other Armoured Vehicles 1900-1918. Blandford Press, London (1970). 170-171., 182-183. o.;

- Zaloga, Steven J.: German Panzers 1914-18 (New Vanguard 127). Osprey, Oxford (2006). 7-9., 12., 41-42. 0 .

\section{JEGYZETEK}

1 Fontos hangsúlyozni, hogy egyes korábban megjelent szakirodalomban írtakkal ellentétben, az LK II-sel kapcsolatban szó sem volt svédországi harckocsigyártásról, pusztán összeszerelésről. 2 Joseph Vollmer (1871-1955) német gépjármű tervezőmérnök, a német harckocsi-fejlesztés úttörője. Az első világháború során a német hadsereg tisztjeként ő volt a főkonstruktőre a Nagy Háborúban egyetlen be is vetett német tank típusnak, az A7V nehéz harckocsinak, valamint a már végül el nem készült K-Wagen 120 tonnás szupernehéz harckocsinak, illetve az LK I és LK II német könnyủ páncélos típusoknak is. A háború után, az 1920-as, '30-as évek során Vollmer - mivel Németországban a versailles-i béke tiltásai miatt nem folytathatta tovább harckocsikkal kapcsolatos munkáit - Csehszlovákia részére tervezett páncélosokat, köztük például a KH-50 „Kolo-Housenkát” is. A témában korábban megjelent monográfiák és szakcikkek valamiért tévedésből az ô nevéhez füzik a '30-as évekbeli, a svéd Landsverk vállalat által gyártott harckocsik megkonstruálását is, holott azok valójában a szintén német mérnök, Otto Merker nevéhez füződnek.

$3 \mathrm{Az}$ LK I-eshez képest a futómủ rövidebb lett és az elejét megemelték, hogy könnyebben tudjon magasabb akadályokon átkelni. Továbbá az LK I-esnél, mint ahogy a korai brit harckocsiknál is, gondot okozott a felfüggesztés sárral, porral való eltömődése, mivel a láncra rátapadt piszok és törmelék hajlamos volt összegyülni a hernyótalp felső részénél, s ez képes volt a lánc megakasztására is. Erre megoldásképp a továbbfejlesztett LK II-en már a felfüggesztés oldalán nyilásokat alakítottak ki, hogy a láncra tapadt sárnak és pornak lehullva legyen hol távoznia. Elképzelhető, hogy az ötletet az akkoriban egyre nagyobb számban megjelenő brit Whippet harckocsiról másolták le a német tervezők.

4 Egyes szakirodalmak ez utóbbi, előrefelé dőlő orr-résszel épített változatot emlegetik tévesen LK III-as néven.

5 A trianoni békét becikkelyező magyar 1921. évi XXXIII. törvénycikk 119. §-ának értelmében „....tilos páncélos járműveket, tankokat vagy hadicélokra felhasználható más hasonló gépeket Magyarországon gyártani és Magyarországba behozni”. A szöveg - az ország nevét leszámítva - szó szerint megegyezik a Németországra vonatkozó, ugyanilyen tiltásokat foganatosító versailles-i békeszerződés 171. §-ával.

6 A páncéltesteket szétszerelve évekig vasúti vagonokba rejtve utaztatták keresztül-kasul Magyarországon, míg az alvázakat mezőgazdasági gépnek álcázva megbízhatónak ítélt gazdaságokban tárolták.

7 Korábban azt feltételezték, hogy a korai, ágyúval szerelt, hátrafelé dőlő orr-résszel kialakított LK II-es volt a német fejlesztési folyamat vége, és a forgótoronnyal, illetve előrefelé dỏlő, zárt orr-résszel épült LK II-eseket / Strv m/21-est már a svédek fejlesztették ki német tervek alapján, akár Joseph Vollmer személyes segítségével is. Azonban rendelkezésre álló történelmi források tanúsága szerint az 1930-as évek legelejéig (az Strv m/21-29-esig) nem alkalmaztak ilyen léptékủ módosításokat az eredeti LK II-eshez képest. Joseph Vollmert pedig - aki 1923 és 1930 között Csehszlovákia részére tervezett harckocsikat - semmilyen bizonyítható kapcsolat nem füzte svédországi vállalatokhoz, s feltehetően soha nem is járt Svédországban. Levéltári források alapján az LK II-esek svédországi összeszerelését egy Stenger nevű német mérnök felügyelte.

\title{
Olvasóink figyelmébe!
}

\author{
Az elmúlt több mint 50 év [MADUECRNA lapszámai elérhetők \\ a Magyar Tudományos Akadémia REAL-J repozitóriumában: \\ http://real-j.mtak.hu/view/journal/Haditechnika.html
}

